\title{
UNGKAPAN KEARIFAN KULTURAL TENTANG ATURAN ADAT BUJANG GADIS DAN KAWIN DALAM UNDANG-UNDANG SIMBUR CAHAYA KESULTANAN PALEMBANG 1824
}

\author{
Satria Wijaya1, Sahid Teguh Widodo 2, Slamet Subiyantoro 3 \\ satriawijaya5555@gmail.com \\ Prodi Magister Pendidikan Bahasa Indonesia \\ Fakultas Keguruan dan Ilmu Pendidikan \\ Universitas Sebelas Maret, Surakarta, Indonesia
}

\begin{abstract}
Abstrak
Penelitian ini bertujuan untuk mendeskripsikan bentuk, makna, dan fungsi ungkapan kearifan kultural tentang aturan adat bujang gadis dan kawin dalam naskah lama Undang-Undang Simbur Cahaya Kesultanan Palembang 1824. Naskah yang digunakan ialah naskah yang telah ditransliterasikan oleh Abu hanifah 1990 berbahasa Arab Melayu. Jenis penelitian ini adalah penelitian pustaka dengan metode peneilitian kualitatif. Pendekatan penelitian yang digunakan ialah semiotika teks. Ungkapan yang ditemukan berupa ungkapan berbentuk kata dan ungkapan berbentuk frasa. Terdapat dua aspek yang diatur dalam bab ini, yaitu tentang aspek perkawinan dan aspek pergaulan atau interaksi sosial antara laki-laki dengan perempuan. Setelah analisis dilakukan, ungkapan-ungkapan yang tertulis dalam teks aturan adat bujang dan gadis berfungsi sebagai fungsi direktif dan fungsi regulatori dalam fungsi bahasa.
\end{abstract}

\begin{abstract}
Abstrac
This research aims to describe the forms, meanings, and functions of the phrase cultural wisdom about the rules of the customs of the servant girl and marries in the script of the old laws of Simbur Cahaya Kesultanan of Palembang 1824. The paper used is the manuscript that had been transliterated by Abu hanifah 1990 Arabic Malay. This type of research is a research library with method qualitative research. The research approach used is text semiotics. Idiom that found in the form of shaped words and idiom shaped phrases. There are two aspects which is set out in this chapter, which is about aspects of marriage and other aspects of association or social interaction between men with women. After the analysis is perfomed, the written phrases in the text of the rules of the customs of the servant and the girl functions as a function of the directive and regulatory functions in the functions of language.
\end{abstract}

\section{PENDAHULUAN}

Suatu bangsa yang beridentitas tentu bangsa yang memiliki kebudayaan. Kebudayaan asli bangsa Indonesia mempunyai nilai yang sangat tinggi di mata dunia. Indonesia sebagai negara yang memiliki wilayah yang sangat luas, dengan beragam suku, bahasa, dan kebudayaan dari Sabang hingga Merauke, telah melabelkan bangsa ini sebagai sebuah bangsa yang multikultur. Dengan multikulturnya bangsa ini, sudah banyak pula karya tercipta, (Januar, 2017).
Berbicara tentang kebudayaan, dapat dikaitkan pula antara kebudayaan nasional dengan kebudayaan daerah yang tidak dapat dipisahkan peranannya. Kebudayaan nasional dianggap sebagai puncakpuncak kebudayaan daerah, tataran tertinggi perwujudan hasil cipta, rasa, dan karsa masyarakat. Kebudayaan daerah dengan demikian berfungsi untuk menopang dan memotivasi perkembangan kebudayaan nasional, (Ratna, 2016). Menurut Hanifah (1994), bahwa Undang-Undang Simbur Cahaya (UUSC) merupakan salah satu warisan budaya nusantara 
berupa naskah lama, yang pernah diberlakukan pada tahun 1630-1979, sebagai landasan hukum pada masa kesultanan Palembang.

Undang-undang ini setidaknya meliputi enam bab, di antaranya BAB I aturan tentang Adat Bujang Gadis dan Kawin, BAB II tentang Aturan Marga, BAB III tentang Aturan Dusun dan Berladang, BAB IV Aturan Kaum, BAB V tentang Adat Perhukuman, dan BAB VI sebagai lanjutan dari BAB V, yakni tentang Aturan Bahagi Uang Denda.

Tiap bab UUSC meliputi 32 pasal pada BAB I, 29 pasal pada BAB II, 34 pasal dalam BAB III, 19 pasal pada BAB IV, 58 pasal pada BAB V, dan 6 pasal pada BAB VI yang penomorannya seurut dengan BAB V. Sejalan dengan banyaknya pasal di dalam UUSC, peneliti sangat tertarik mengkaji keunikan suatu bahasa lama berupa ungkapanungkapan kearifan kultural yang peneliti temukan di dalam naskah UUSC yang sudah diterjemahkan oleh Abu Hanifah pada 1994.

Naskah yang peneliti gunakan ialah naskah yang telah ditransliterasikan oleh Abu Hanifah. Naskah ini merupakan hasil dari perbaikan pada naskah cetakan pertama Undang-Undang Simbur Cahaya. Dalam proses penyempurnaannya, naskah tersebut berpedomankan Ejaan yang Disesuaikan (EYD) pada saat itu.

Dalam mengatur peradatan masyarakat, Undang-Undang Simbur Cahaya sebelumnya disebut sebagai Undang-Undang Sindang Marga pada masa Pemerintahan Belanda (1824). Kemudian pada 1897, untuk pertama kalinya undang-undang ini dicetak dan disebarluaskan di masyarakat dengan teksnya berbahasa Arab Melayu. Sebutan marga, desa, dan dusun dikenal sebagai sekup terkecil dari wilayahwilayah di Sumatera Selatan. Kemudian, ada pula istilah sultan, pangeran, pasirah, krio atau pembarap, proatin, lebai penghulu, khatib, dan kemit, sebagai perangkat wilayah yang bertugas.

Sebagai salah satu karya kesusastraan lama, hasil karya kesusastraan masa lampau pada umumnya mengandung nilai-nilai luhur yang menjadi sumber pijakan dalam mengarahkan sikap dan tingkah laku masyarakat ke arah kebenaran. Oleh karena itu, sudah sepantasnya apabila ada pemikiran atau perhatian khusus tentang pengungkapan nilai-nilai luhur dari berbagai naskah kuno peninggalan nenek moyang, (Mumfangati, 2017).

Sebagai bagian dari kearifan lokal, ungkapan-ungkapan lama umumnya jarang lagi kita temukan dan digunakan dalam obrolan formal maupun keseharian. Menjadi kompleks pula ketika adanya arus modernitas, justru memperkecil masyarakat terutama generasi muda untuk dapat mempelajari dan mengambil manfaat di dalam ungkapan-ungkapan lama. Padahal, seperti halnya ungkapan UUSC yang tentunya banyak sekali pelajaran yang bisa kita ambil jika kita memahaminya.

Sebagai contoh, ungkapan "naroh gawe", yang maknanya ialah laki-laki menyenggol tangan gadis. Ungkapan tersebut berfungsi sebagai larangan laki-laki menyenggol tangan gadis yang bukan istrinya, namun ketika masih ada laki-laki menyenggol tangan gadis atau perempuan yang bukan istrinya, maka kena denda dua ringgit. 
Apabila kita memahami adanya ungkapan sebagai suatu larangan, tentu tidak akan kita langgar, karena akan mendapatkan denda yang harus dibayarkan. Menyenggol tangan gadis atau perempuan yang bukan istri itu merupakan suatu hal yang tidak boleh dilakukan oleh setiap lakilaki.Inilah yang dimaksud bahwa ungkapan kearifan kultural dalam UUSC sebagai pengenalan warisan kebudayaan nenek moyang leluhur, yang di dalamnya tersirat pesanpesan moral yang patut dipahami.

Generasi muda sebagai penerus kebudayaan harus pandai mengenali kebudayaan lama sebagai warisan budaya. Pengenalan tersebut dilakukan guna mengambil nilai-nilai kebaikan pada warisan budaya, kemudian nilai-nilai kebaikan itu dapat menjadi warna kemajuan di era globalisasi saat ini, (WS, 2015).

Pengkajian ungkapan warisan budaya di Sumatera Selatan relatif masih sedikit. Di Minahasa, suatu kajian etnolinguistik oleh Sjane F. Walangarei (2013), dengan karyanya yang berjudul "Ungkapan Lisan Bermakna Budaya, suatu Tinjauan Etnolinguistik". Ungkapan yang telah diteliti di masyarakat Minahasa, Tondano, mengandung nasihat dan sindiran.

Ada juga penelitian tentang ungkapan kebudayaan yang judulnya, yakni "Kearifan Lokal dalam Tradisi Lisan Kepercayaan Rakyat Ungkapan Larangan Tentang Kehamilan, Masa Bayi,dan KanakKanak Masyarakat Minangkabau Wilayah Adat Luhak Nan Tigo" oleh Hasanuddin WS (2015), yang diketahui bahwa nilai tradisi Minangkabau wilayah adat Luhak Nan Tigo memiliki pengetahuan tentang alam natural dan supranatural, kemudian menanamkan nilai-nilai pendidikan seseorang dari sejak bayi sampai menjalani kehidupan di dunia.

Sebagai salah satu cara dalam mengenali dan memahami warisan budaya yang menyiratkan pelajaran tentang baik dan buruknya suatu perbuatan, penelitian ini dilakukan dengan fokus kajiannya pada bentuk, makna, dan fungsi ungkapan kearifan kultural Undang-Undang Simbur Cahaya tentang aturan adat bujang gadis dan kawin pada masa kesultanan Palembang.

\section{KAJIAN TEORI}

Ungkapan kearifan kultural yang dibahas dalam penelitian ini merupakan ungkapan lama yang sudah tidak digunakan lagi dalam bahasa sehari-hari. Ungkapan lama ini menjadi bagian dari ungkapan yang bersifat tradisional, sehingga topik ini berkaitan pula dengan kajian ilmu folklor.

Kata folklor pun nyatanya masih sedikit asing di pendengaran kita. Menurut Danandjaja (1991), bahwa folklor sendiri berawal dari bahasa asing, dengan kata folklore dalam bahasa Inggris. Kata folk sama artinya dengan kata kolektif, sedangkan lore adalah tradisi folk, yaitu sebagian kebudayaannya telah diwariskan ke genarasi-generasi melalui suatu contoh yang disertai dengan gerak isyarat atau alat pembantu pengingat (mnemonic device).

Bahasa yang digunakan dalam kehidupan sehari-hari ialah bahasa lisan dan bahasa tulisan dengan segala fungsi dan kegunaannya masing-masing dalam suatu tuturan komunikasi. Bahasa ini digunakan untuk berkomunikasi antar anggota 
masyarakat dalam berbagai bidang dan berbagai tema, untuk bertegur sapa, bercerita, berniaga, bahkan bertengkar, dan merayu. Oleh karena itu, dalam bahasa sehari-hari ada kata-kata yang digunakan untuk bertegur sapa saja (mengaktifkan fungsi fatik bahasa), kosakata berkaitan dengan sopan santun, kosakata bidang agama, sampai koleksi carut, koleksi makian, (Amir, 2013).

Uniknya dalam bahasa ialah adanya suatu peribahasa. Dalam hal ini, menurut Danandjaja (1991), peribahasa yang sesugguhnya adalah ungkapan tradisional yang mempunyai sifat-sifat, yakni kalimatnya lengkap, bentuknya biasanya kurang mengalami perubahan, dan mengandung kebenaran atau kebijaksanaan. Begitu juga dengan ungkapan dalam kajian penelitian ini yang juga merupakan bagian dari produk kajian sosiolinguistik, yang mengandung makna dan fungsi tertentu dalam bahasa.

Sosiolinguistik adalah cabang
ilmu linguistik yang bersifat interdisipliner degan ilmu sosiologi, dengan objek penelitian hubungan antara bahasa dengan faktor-faktor sosial di dalam suatu masyarakat tutur. Sosiolinguistik lebih berhubungan dengan perincianperincian penggunaan bahasa yang sebenarnya, seperti deskripsi polapola pemakaian bahasa/dialek dalam budaya tertentu, pilihan pemakaian bahasa/dialek tertentu yang dilakukan penutur, topik, dan latar pembicaraan, (Chaer, 2010).

Menurut Simanjuntak (2014: 32), bahwa kebudayaan masyarakat hukum adat memiliki nasihat-nasihat, petuah-petuah, ajaran-ajaran, bahkan aturan mengatur cara hidup manusia dalam pergaulan sesama mereka, dengan orang yang dituakan dan diangkat menjadi pemimpin, dalam hubungan dengan hak dan kewajiban, dalam hubungan dengan alam lingkungannya, dalam hubungan dengan waktu, hujan, panas, iklim, dan lain sebagainya.

Sejalan dengan pendapat di atas, Undang-Undang Simbur Cahaya yang terdiri dari enam bab diterapkan di daerah pedalaman Kesultanan Palembang dan mengatur segala urusan di tengah keberlangsungan kehidupan masyarakat sehari-hari.

Bab 1 mencakup sebanyak 32 pasal yang mengatur tentang "Adat Bujang Gadis dan Kawin (Perkawinan)". Bab 2 tentang "Aturan Marga" yang mencakup 29 pasal. Bab 3 tentang "Aturan Dusun dan Berladang" yang memiliki 34 pasal. Selanjutnya, bab 4 yang mencakup 19 pasal yang mengatur tentang "Aturan Kaum". Bab 5 sebanyak 58 pasal mengatur tentang “Adat Perhukuman". Terakhir, bab 6, berisi tentang "Aturan Bahagi Uang Denda" yang mencakup 6 pasal.

\section{METODE PENELITIAN}

Penelitian ini berjenis penelitian pustaka (library research) dengan metode penelitian kualitatif. Menurut Sugiyono (2014), bahwa metode penelitian kualitatif dapat diartikan sebagai metode penelitian yang berlandaskan pada filsafat postpositivisme/enterpretatif,

digunakan untuk meneliti pada 
kondisi obyek alamiah, (sebagai lawannya adalah eksperimen), dimana peneliti sebagai instrumen kunci. Teknik pengumpulan data dilakukan secara trianggulasi (gabungan), analisis data bersifat induktif/kualitatif, dan hasil penelitian kualitatif lebih menekankan makna dari pada generalisasi.

Selain itu, analisis yang digunakan dalam penelitian ini adalah analisis bentuk, makna, dan fungsi melalui pendekatan semiotika teks melalui teknik analisis teks atau isi. Menurut Piliang (2004), Analisis teks (textual analysis) adalah salah satu cabang dari semiotika teks, yang secara khusus mengkaji teks sebagai sebuah 'produk penggunaan bahasa' berupa kumpulan atau kombinasi tanda-tanda, khususnya yang menyangkut sistem tanda (sintaktik/paradigmatik), tingkatan tanda (denotasi/konotasi), relasi antartanda (metafora/metonim), muatan mitos, dan ideologi dibaliknya.

Analisis isi dilakukan terhadap sumber data naskah Undang-Undang Simbur Cahaya Kesultanan Palembang yang telah ditrasliterasikan oleh Abu Hanifah pada tahun 1994. Kemudian, data berupa ungkapan-ungkapan lama yang dikumpulkan merupakan temuan-temuan yang dijadikan sebagai objek pemahaman dalam penelitian ini.

\section{HASIL DAN PEMBAHASAN}

Sesuatu yang sangat nampak
ketika berkomunikasi ialah
ungkapan. Ungkapan di sini bisa
berbentuk kata maupun frasa, kedua
hal tersebut merupakan elemen yang

yang sangat nampak dalam bahasa, khususnya saat berkomunikasi. Menurut Chaer (2015: 14), bahwa setiap makhluk hidup di dunia ini memiliki alat komunikasi yang bisa digunakan untuk berkomunikasi atau berinteraksi sesamanya. Alat komunikasi manusia namanya bahasa. Karena bahasa merupakan sesuatu yang "ada" (being).

Ungkapan berbentuk kata maupun frasa memang bersumber dari interaksi sosial secara alami. Dalam teori "yo-he-ho", bahwa bunyi yang dihasilkan seseorang yang sedang melakukan kegiatan fisik itu melibatkan beberapa orang dan interaksi tersebut harus dikoordinasikan. Dengan demikian, sekelompok manusia zaman dahulu mungkin mengembangkan serangkaian dengungan, dengkuran, erangan, dan umpatanyang digunakan ketika mereka sedang mengangkat dan membawa potongan besar pohon atau mamouth berbulu yang telah mati, Yule (2015: 5).

Hal menarik dari beberapa ungkapan lama atau dalam hal ini sebagai suatu ungkapan kearifan kultural di masa kesultanan Palembang, dan terwujudkan sebagai sebuah wacana lisan yang tertuliskan dalam teks Undang-Undang Simbur Cahaya yang merepresentasikan berbagai dampak dari interaksi sosial saat itu, kenyataannya memberikan gambaran penciptaan sebuah bahasa.

Sebagaimana wacana lisan, maka setiap wacana sebenarnya lahir dalam konteks situasi kebudayaan dan kondisi-kondisi sosial tertentu. 
Dalam wacana lisan, kondisikondisiitu tampak jelas, karena wacana diujarkan dalam bahasa tertentu dan dalam lingkungan tertentu. Wacana lisan sangat terikat dengan konteks yang merupakan kondisi sosial-budaya, maka tidak halnya dengan teks. Teks dapat melepaskan kondisi di mana ia lahir dan dapat memasuki situasi sosialbudaya baru, MPSS (2015: 146147).

Isi teks pada BAB I tentang Aturan Adat Bujang Gadis dan Kawin ini mencakup sebanyak 32 pasal. Dari pasal-pasal tersebut, 20 ungkapan yang ditemukan memiliki bentuk, makna, dan fungsinya masing-masing. Bentuk, makna, dan fungsi ungkapan tersebut menunjukkan adanya kondisi sosialbudaya pada masa itu. Hasilnya dapat kita pahami ulasan dalam berikut ini:

\section{Bentuk Ungkapan Aturan Adat} Bujang Gadis dan Kawin

Ada dua bentuk ungkapan dalam bab ini, yaitu ungkapan berbentuk kata dan ungkapan berbentuk frasa. Ungkapan yang berupa kata, di antaranya sebagai berikut:

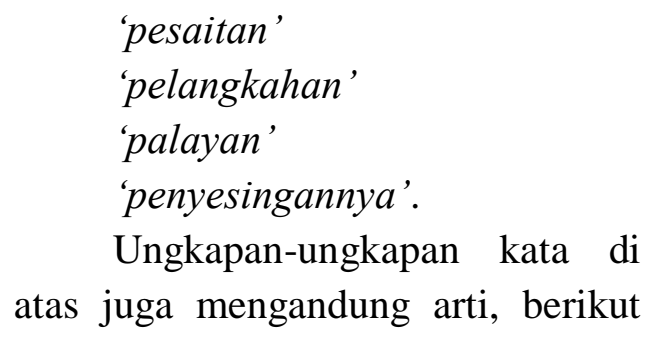
atas juga mengandung arti, berikut ulasannya:

tebusan' pelangkahan 'mendahului menikah'

palayan 'sejenis denda'

penyesingannya 'ganti

kerugian'

Selanjutnya adalah ungkapan yang berbentuk kelompok kata yang lebih dari satu kata atau istilahnya, yaitu frasa, dapat kita pahami seperti di bawah ini:

'taming buka lawang'

'nangkap batin'

'naroh gawe'

'merenggang gawe'

'nangkap rimau'

'bengkarung jengak-jengul'

'ayam satu bertembung dua'

'kembang melilit gedang'

'lang menarup buaya'

Secara lingual masyarakat Palembang dan sekitarnya, ungkapan berbentuk frasa tersebut dapat pula diartikan sebagai berikut:

taming buka lawang 'alat membuka pintu'

nangkap batin 'mendekap

tubuh atau badan'

naroh gawe 'buat ulah atau

kerjaan'

merenggang gawe 'memeluk

sampai memperkosa

perempuan'

nangkap rimau 'menangkap

macan'

bengkarung jengak-jengul

'sejenis hewan kadal yang

mengintip atau mengintai'

ayam satu bertembung dua '

kembang melilit gedang

'bunga melilit besar' 
lang menarup buaya 'sejenis burung elang menghampiri buaya'

\section{Makna Ungkapan Aturan Adat Bujang Gadis dan Kawin}

Makna yang dapat dipahami dari ungkapan-ungkapan yang ada, bersumber dari makna tekstual pada tiap pasalnya secara utuh.

Pertama, ungkapan 'pesaitan', yang berarti uang tebusan atau uang syarat. konteksnya hampir sama dengan ungkapan 'terang', ungkapan 'pesaitan' di dalam pasal 2, yakni "Jika rangdo hendak kawin, mesti sanaknya dan sanak yang bakal lakinya memberi tahu pada Kepala Dusun, dan laki-laki membayar pesaitan satu ringgit pada Pasirah atau Kepala Dusun, dan dibahagi bagaimana tersebut pasal 1." Maknanya tidak jauh berbeda dengan ungkapan di pasal 1 , hanya saja yang sangat berperan adalah laki-laki yang hendak menikah, membayar sejumlah uang tebusan saturinggit kepada pasirah atau kepala dusun.

Kedua,

'pelangkahan', yang berarti mendahului atau melangkahi. Ungkapan ini maksudnya ialah jika seorang perempuan (gadis) yang akan menikah, tetapi masih ada kakaknya yang belum menikah, maka laki-kaki (bujang) yang akan menjadi suami gadis tersebut hendaknya membayar adat 'pelangkahan' kepada gadis tersebut untuk diserahkan kepada kakaknya. Hal demikian juga sebagai wujud penghormatan dan restu kakak gadis tersebut agar adiknya melangsungkan pernikahan dengan tanpa kesedihan kakaknya.

Ketiga, ungkapan 'palayan', yang berarti sejenis denda. Ungkapan ini terdapat pada pasal 6, yakni "Jika bujang gadis bergubalan tiada bunting atau bujang bambang gadis, bujang itu kena denda palayan 6 ringgit, dan bujang gadis itu hendak dikawinkan bagaimana adat terang tiada membayar lagi upah batin. Dari palayan 6 ringgit, 1 ringgit pulang pada Pasirah, amit menutup surat namanya, 3 ringgit pulang pada kepala dusun dan 2 ringit pada penggawa-penggawanya. Dan jika bujang gadis lain-lain marga atau dusun, denda itudibahagi dua, sebahagi pulang pada Pasirah, Proatin dan Penggawa marga atau dusun bujang dan sebahagi pulang pada Pasirah, Proatin, dan Penggawa marga atau dusun gadis."

Ungkapan 'penyesingannya', yang berarti ganti rugi. Ungkapan ini terdapat pada pasal 13, yakni "Jika bujang gadis bertunangan dengan terang, maka gadis itu dibambang bujang yang lain atau ahli gadis mungkin tiada suka lagi pada bujang yang bertunang, tiada dengan sebabnya yang patut, bapak gadis itu kena 8 ringgit penyensingannya namanya, pada bujang, lagi kerugiannya ditimbang atas kepatutan Pasirah, Proatin." Ungkapan ini bermakna jika bujang dan gadis sudah bertunangan dengan terang, maka salah satu pihak tidak boleh memutuskan pertunangan tersebut tanpa didasari musyawarah

104 | Jurnal Kredo 
ataupun kerelaan dari bujang dan gadis yang bertunangan untuk membatalkan itu. Dalam hal ini pula, ungkapan tersebut menunjukkan bahwa adanya rasa yang tidak lagi suka dari ayah gadis yang bertunang kepada bujang, yang mengakibatkan gadis dibawa lari oleh laki-laki lain tanpa alasan yang jelas dan terang, maka ayah gadis didenda delapan ringgit.

Selanjutnya, ungkapan 'taming buka lawang', yang berarti alat atau sebagai cara membuka pintu. Ungkapan ini terdapat di dalam pasal lima, yang juga sama dengan ungkapan 'pengamitan' dan 'pelangkahan' setelah ungkapan ini. 'taming buka lawang' mempunyai makna secara tekstualnya, yakni lakilaki membayar satu ringgit kerpada ibu dari perempuan yang akan dinikahinya. Hal demikian dimaksudkan untuk membuka jalan atau restu dari orangtua perempuan tersebut. Berikut pasal yang mencakup ungkapan ini:

"Dan bujang yang kawin jka suka boleh bayar adat lama, bagaimana tersebut di bawah ini:Upah beranak 4 ringgit; mas bunga kuku 1 ringgit atau cincin harga 1 ringgit; pengamitan, waktu gadis turun dari rumah, 1 ringgit, tiga pasal ini bujang bayar pada gadis punya orang tua perempuan maka orang tua membalas dengan tikar, bantal, dan selimut; pesujutan, waktu bujang hendak bawa isterinya ia sujud pada mertuanya 1 ringgit, yaitu $1 / 2$ ringgit pada bapak dan $1 / 2$ ringgit pada mak isterinya; taming buka lawang, 1 ringgit, bujang bayar pada mak gadis; pelangkahan, 2 ringgit, jika gadis yang kawin ada kakaknya yang belum berlaki hendak bujang membayar padanya adat pelangkahan 2 ringgit, dan jika rangdo kawin tidak pakai pembayaran yang tersebut di atas ini, melainkan boleh bayar adat pengamitan 1 ringgit."

$$
\text { Selanjutnya ungkapan }
$$

'nangkap batin', yang berarti menangkap badan atau tubuh. Ungkapan ini terdapat di dalam pasal 15, yakni "Jika bujang gadis bertunang, maka rasa bujang terlambat dikawinkan lantas nangkap batin, hendaklah bujang itu dikawinkan dengan tunangannya serta ia kena palayan 6 ringgit." Makna dari ungkapan ini, yaitu pertunangan yang sudah terlalu lama dan belum terjadi pernikahan, hal itu mengakibatkan bujang melepaskan hasrat atau keinginan menyentuh tubuh gadis tunangannya, bujang itu didenda enam ringgit dan harus segera dinikahkan dengan tunangannya.

Ungkapan 'naroh gawe'. Ungkapan ini artinya tidak ada kerjaan. Ungkapan tersebut terdapat pada pasal 18, yakni "Jika laki-laki senggol tangan gadis atau rangdo, naroh gawe namanya, ia kena denda 2 ringgit jika perempuan itu mengadu. Dan 1 ringgit pulang pada perempuan itu dan 1 ringgit pada kepala dusun serta penggawanya." Makna dari ungkapan ini, yaitu lakilaki dilarang menyenggol atau menyentuh tangan gadis atau janda 
yang bukan haknya. Jika hal demikian terjadi didenda dua ringgit, dengan syarat perempuan mengadukan kejadian tersebut.

Selanjutnya makna Ungkapan 'merenggang gawe', yang berarti perbuatan tercela. Maksud dari ungkapan ini ialah laki-laki memegang sampai memeluk tubuh gadis atau janda merupakan suatu pelanggaran yang merusak norma kesopanan dan pelecehan terhadap wanita, dan lelaki tersebut kena denda dua belas ringgit. Ungkapan ini terdapat pada pasal 21, yakni "Jika laki-laki pegang gadis atau rangdo lantas peluk badannya, merenggang gawe namanya, ia kena denda 12 ringgit jika perempuan itu mengadu. Dan 6 ringgit pulang pada perempuan itu, dan 6 ringgit pada pasirah, jika di dusun pasirah, jika di dusun pengandang 3 ringgit: pulang pada pasirah, dan 3 ringgit pada kepala dusun dan penggawanya."

Selanjutnya 'nangkap rimau'. Arti ungkapan ini ialah menangkap macan. Ungkapan ini terdapat pada pasal 22, yakni "Jika bujang nangkap badan gadis atau rebut kainnya atau kembannya tiada dengan suka gadis atau ahlinya gadis, nangkap rimau namanya, maka bujang itu kena denda 12 ringgit lagi ia bayar pada gadis 8 ringgit." Ungkapan ini bermakna, bahwa adanya larangan keras atas tindakan seorang laki-laki menangkap badan hingga merebut kain atau kemban (pakaian) penutup tubuh gadis, dengan maksud untuk melakukan hubungan biologis dengan gadis, maka tindakan itu termasuk pelanggaran besar yang tidak patut, sehingga laki-laki pelanggar tersebut didenda dua belas ringgit, dan jika gadis tersebut tidak suka atas tindakan itu, laki-laki harus membayar denda delapan ringgit yang diserahkan kepada gadis.

$$
\text { Pada pasal } 29 \text { terdapat }
$$

ungkapan 'bengkarung jengakjengul', yang dalam bahasnya bengkarung merupakan sejenis hewan reptil, yakni kadal, sedangkan jengak-jengul berarti mengintip atau mengintai dalam persembunyian. Berdasarkan teksnya, "Siapa yang melikas orang perempuan mandi serta yang lanang bersembunyi, bengkarung jengak-jengul namanya, kena 4 ringgit." Tersurat makna bahwa jika seseorang mengintip perempuan mandi akan didenda empat ringgit. Perbuatan mengintip merupakan perilaku tercela yang tidak patut dilakukan oleh siapa pun.

Pada pasal 30, yakni “Jika orang yang punya anak gadis bersan dengan bujang dua atau tiga akan jadi mantunya, ayam satu bertembung dua namanya, kena harga kerbau atau kena denda 6 ringgit,3 ringgit pada pasirah 3 ringgit pada orang yang urung jadi mantunya." Ungkapan 'ayam satu bertembung dua' yang berarti dalam suatu pernikahan terdapat satu perempuan, akan tetapi ayah perempuan mempertemukan dua sampai tiga laki-laki yang akan dijadikan mantunya, ayah atau pihak 
wali perempuan tersebut kena denda enam ringgit, tiga ringgit diserahkan kepada pasirah, tiga ringgit lagi kepada orang yang batal jadi mantunya.

Kemudian pada pasal 31, yakni "Jika ada bujang nabuh suling keliling rumah yang ditunggu gadis, maka tuan rumah tiada suka, kembang melilit gedang namanya, bujang kena denda 4 ringgit." Terdapat ungkapan 'kembang melilit gedang', yang berarti kembang melilit atau mengelilingi sesuatu yang besar. Makna dari ungkapan itu ialah jika laki-laki yang ditunggu gadisnya untuk datang ke rumah, namun ketika itu laki-laki tersebut menabuh suling sampai mengelilingi rumah gadis tersebut lantas tuan rumah gadis tersebut tidak suka, maka laki-laki tersebut kena denda empat ringgit.

Ungkapan terakhir, dalam pasal 32, sebagai penutup pada bab ini, terdapat ungkapan 'lang menarup buaya' yang berarti sejenis burung elang yang mencakar atau mencabik badan buaya. Namun dalam teksnya, yaitu "Jika bujang gadis berjalan maka bujang rebut kembang dari kepala gadis, lang menarup buaya namanya. Bujang kena denda 2 ringgit." Ungkapan tersebut mempunyai makna jika bujang dan gadis berjalan, kemudian bujang tersebut mengambil kembang yang berarti benda yang berharga milik gadis, bujang kena denda dua ringgit.

\section{Fungsi Ungkapan Aturan Adat Bujang Gadis dan Kawin}

Mengenai fungsi suatu ungkapan, baik dalam konteks komunikasi lisan maupun tulisan, tentu tidak dapat dipisahkan dengan bagaimana ungkapan itu sendiri digunakan dalam berbahasa. Selain itu, fungsi ungkapan juga dapat kita pahami sebagai bagian dari isi sebuah teks.

Sejalan dengan pemahaman di atas, ternyata tidak ada perbedaan antara ulasan tentang analisis bentuk dan isi dengan analisis bentuk, makna, dan fungsi. Hal itu dikarenakan fungsi dan makna merupakan isi yang menjadi inti sebuah pembahasan dalam kajian ini. Setiap gejala kultural memiliki bentuk, kemudian bentuk tersebut memiliki fungsinya masing-masing, yang pada gilirannya akan memberikan makna tertentu, (Ratna, 2016).

Ungkapan lama sebagai suatu bahasa yang ada dalam penelitian ini merupakan wujud terjadinya komunikasi dalam aktivitas kehidupan masyarakat saat itu. Yang kemudian komunikasi tersebut melahirkan bentuk-bentuk bahasa yang khasa atau dapat dikatakan unik. Itu artinya ungkapan juga termasuk ke dalam bahasa. Adanya suatu bentuk ungkapan dalam komunikasi dapat mendukung suatu fungsi bahasa.

Menurut Pranowo (2015), bahwa fungsi bahasa adalah cara bagaimana bahasa itu digunakan. Dengan demikian, fungsi 
komunikatif bahasa adalah bagaimana cara bahasa itu digunakan untuk berkomunikasi. Dalam kaitannya fungsi spesifik pemakaian bahasa dalam kegiatan berkomunikasi, setidaknya ada sebelas fungsi bahasa, di antaranya fungsi informatif, transaksional, interaksional, komisif, direktif, konatif, ekspresif, regulatori, heuristik, instrumental, dan fungsi imajinatif.

Pada ungkapan-ungkapan dalam penelitian ini, telah dipahami bahwa kecenderungan ungkapan yang tertulis berdasarkan fungsinya, berfungsi sebagai fungsi direktif dan regulatori dalam fungsi bahasa.

Fungsi direktif yang dimaksud adalah bahwa bahasa dapat digunakan untuk mengajukan saran, membujuk, permintaan, meyakinkan orang lain, dan sebagainya. Fungsi direktif ini memiliki sub fungsi, seperti untuk meyakinkan, untuk memberi kritik, untuk mengharapkan sesuatu, untuk membujuk, untuk memberi saran, dan untuk memerintah secara tidak langsung, dan sebagainya. Dapat pula kita perhatikan pada teks berikut ini:

Pasal 2: "Jika rangdo

hendak kawin, mesti sanaknya dan sanak yang bakal lakinya memberi tahu pada Kepala Dusun, dan lakilaki membayar pesaitan satu ringgit pada Pasirah atau Kepala Dusun, dan dibahagi bagaimana tersebut

pasal 1."

Ungkapan pesaitan di atas berfungsi sebagai fungsi direktif bahasa. Yang menandakan adanya fungsi direktif bahasa ialah adanya kata 'mesti' yang mempunyai makna keharusan seseorang untuk melakukan sesuatu, bisa diartikan pula sebagai suatu perintah yang harus dilakukan orang lain. Dalam hal ini kaitannya adalah aturan yang telah ditetapkan dalam kelompok masyarakat.

Pasal 5: "waktu bujang

hendak bawa isterinya

ia sujud pada

mertuanya 1 ringgit,

yaitu $1 / 2$ ringgit pada

bapak dan $1 / 2$ ringgit

pada mak isterinya;

taming buka lawang, 1

ringgit, bujang bayar

pada mak gadis"

Sama halnya dengan ungkapan sebelumnya, ungkapan 'taming buka lawang' juga berfungsi sebagai fungsi direktif bahasa. Adanya kata 'hendak', yang merupakan suatu perintah bagi seseorang untuk melakukan apa yang harus dilakukan. perintahnya, yakni jika laki-laki mau membawa istrinya pergi bersama menjalani ikatan keluarga yang baru, sebaiknya sujud minta restu terlebih dahulu kepada ibu istrinya dengan membayarkan atau memberikan sejumlah uang sebagai tanda terima kasih ataupun suatu penghormatan, sehingga terbukalah kelegaan orang tua 
melepaskan anaknya pergi bersama suaminnya.

Sama halnya dengan ungkapan 'pelangkahan' yang berfungsi sebagai direktif dalam fungsi bahasa. Karena aspek penanda yang dominan terlihat ialah pada kata 'hendak', yang juga merupakan suatu bentuk saran ataupun perintah agar orang lain melakukan sesuatu itu. Seperti dalam kutipan pasal 5 berikut ini:

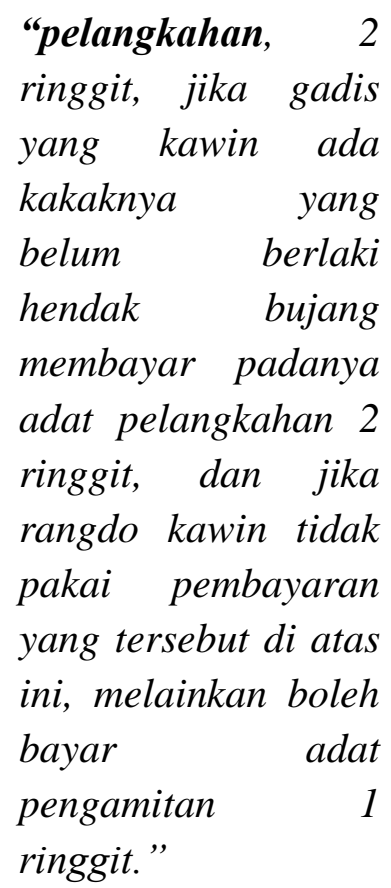

Selanjutnya fungsi regulatori. Fungsi regulatori adalah bahwa bahasa dapat digunakan untuk mengontrol suatu peristiwa. Misalnya, "berdasarkan hukum tata negara, pemilihan kepala desa dengan membagi-bagikan uang jelas menyalahi aturan. Hal demikian tidak boleh, (Pranowo, 2015)." Perhatikan teks berikut:

Pasal 6: "Jika ada laki-

laki melarikan

perempuan ke rumah

kepala dusun di tempat tinggalnya

tetapi perempuan

tersebut belum

mengandung atau

hamil, laki-laki itu itu

kena denda palayan 6

ringgit, dan laki-laki

perempuan itu harus

dinikahkan sesuai adat

terangmasyarakat saat

itu, sebagaimana adat

terang tiada

membayar lagi upah

batin. Dari palayan 6

ringgit, 1 ringgit

pulang pada Pasirah,

amit menutup surat

namanya, 3 ringgit

pulang pada kepala

dusun dan 2 ringit

pada penggawa-

penggawanya.

Ungkapan 'palayan'

berfungsi sebagai regulatori, hal ini disebabkan karena dengan diungkapkannya ungkapan tersebut, seseorang diharapkan dapat mengontrol dirinya untuk tidak melakukan perbuatan yang tidak diperbolehkan, hal demikian tentu akan menerima denda atau hukuman ketika melanggar aturan tersebut.

Kemudian pada pasal 21 di bawah ini:

"Jika laki-laki

pegang gadis atau

rangdo lantas peluk

badannya,

merenggang gawe

namanya, ia kena

denda 12 ringgit 
jika perempuan itu

mengadu."

Pada ungkapan 'merenggang gawe' makna yang bisa diambil ialah laki-laki tidak boleh memegang gadis hingga memeluk badan gadis itu yang bukan istrinya, hal demikian merupakan sebuah pelanggaran, jika itu terjadi denda akan didapatkan oleh laki-laki yang melanggarnya.

Pasal 29: "Siapa

yang melikas orang

perempuan mandi

serta yang lanang

bersembunyi,

bengkarung

jengak-jengul

namanya, kena 4

ringgit."

Pada teks di atas, ungkapan 'bengkarung jengak-jengul' mempunyai makna terlarangnya seseorang mengintip perempuan yang sedang mandi di tempat pemandian, baik di rumah ataupun sungai pemandian masyarakat, perbuatan tersebut merupakan kelakuan buruk yang tidak terhormat. Jika itu tetap terjadi, berarti orang tersebut melanggar aturan yang berlaku dan mendapatkan denda sesuai ketetapan dalam aturan. Itulah ungkapan yang dikatakan berfungsi sebagai fungsi regulatori, dimana dengan adanya ungkapan ini dapat pula mencegah ataupun mengontrol tindakan buruk seseorang kepada orang lain.

Sama halnya dengan ungkapan 'lang menarup buaya' yang bermakna larangan bujang atau laki-laki yang berjalan dengan seorang perempuan, kemudian lakilaki itu merampas barang berharga yang dimiliki perempuan tersebut, tentu laki-laki tersebut mendapatkan denda atas pelanggaran yang dilakukan.

\section{SIMPULAN}

Berdasarkan pembahasan di atas dapat ditarik sebuah simpulan, bahwa ungkapan lama yang dikaji dalam penelitian ini tereksplisitkan pada dua aspek fenomena adat bujang gadis dan perkawinan, aspek pertama tentang pernikahan, kedua, tentang pergaulan antara laki-laki dengan perempuan di masyarakat yang menggambarkan banyaknya suatu perbuatan buruk yang harus dicegah dan dikontrol. Fungsi utama dari ungkapan-ungkapan yang ada ialah sebagai fungsi direktif dan fungsi regulatori dalam bahasa.

\section{DAFTAR PUSTAKA}

Amir, A. (2013). Sastra Lisan Indonesia. Yogyakarta: Andi.

Chaer, Abdul. 2015. Filsafat Bahasa. Jakarta: PT Rineka Cipta.

Chaer, Abdul, dan L. A. (2010). Sosiolinguistik (Perkenalan Awal). Jakarta: PT Rineka Cipta.

Danandjaja, J. (1991). Folklor Indonesia (Ilmu Gosip, dongeng, dan lain-lain) (Ketiga). Jakarta: PT Pustaka Utama Grafiti.

110 | Jurnal Kredo

Vol. 2 No. 1 Oktober 2018 
Hanifah, A. (1994). Undang-Undang Simbur Cahaya. Jakarta: Pusat Pembinaan dan Pengembangan Bahasa Departemen Pendidikan dan Kebudayaan.

Januar, Arie. 2017. Fungsi, Makna, dan Eksistensi Noken sebagai Simbol Identitas Orang Papua. Jurnal Patrawidya, Vol. 18 (1), 57-70.

MPSS, Pudentia. 2015. Metodologi Kajian Tradisi Lisan. Jakarta: Yayasan Pustaka Obor Indonesia.

Mumfangati, Titi. 2017. Kajian Nilai Budaya dalam Serat Wulang Pandhita Tekawardi. Jurnal Patrawidya, Vol. 18 (2): 203-220.

Piliang, Y. A. 2004. Semiotika Teks: Sebuah Pendekatan Analisis Teks. Jurnal Mediator, Vol. 5 (2): 189-198.

Pranowo. 2016. Teori Belajar Bahasa. Yogyakarta: Pustaka Pelajar.

Ratna, N. K. (2016). Metodologi Penelitian Kajian Budaya dan Ilmu Sosial Humaniora pada Umumnya (2nd ed.). Yogyakarta: Pustaka Pelajar.

Simanjuntak, Bungaran Antonius. 2014. Korelasi Kebudayaan dan Pendidikan. Jakarta: Yayasan Pustaka Obor Indonesia.

Sugiyono. (2014). Metode Penelitian Manajemen. (Setyawami, Ed.). Bandung: CV Alfabeta.

Walangarei, S. F. (2013). Ungkapan Lisan Bermakna Budaya, Suatu Tinjauan Etnolinguistik. Ranah, 2, nomor 1, 58-68.

WS, H. (2015). Kearifan Lokal dalam Tradisi Lisan Kepercayaan Rakyat Ungkapan Larangan tentang Kehamilan, Masa Bayi, dan Kanak-kanak Masyarakat Minangkabau wilayah Adat Luhak Nan Tigo. Kembara, 1, nomor 2, 198-204.

Yule, George. 2015. Kajian Bahasa. Yogyakarta: Pustaka Pelajar. 